\title{
Obez ve Obez Olmayan Polikistik Over Sendromlu Adolesanların Klinik ve Laboratuvar Özelliklerinin Karşılaştırılması
}

\section{Comparison of The Clinical and Laboratory Characteristics of Obese and Non-Obese Adolescents with Polycystic Ovary Syndrome}

\author{
Aynur BEDEL, Hale TUHAN, Eren İSMAİLOĞLU, Deniz ÖZALP KIZILAY, Sezer ACAR ${ }^{4}$ \\ 1 Akdeniz Üniversitesi Tıp Fakültesi, Çocuk Endokrinoloji Bilim Dalı, Antalya, Türkiye \\ 2 Çiğli Bölge Eğitim Hastanesi, Çocuk Endokrinoloji Kliniği, İzmir, Türkiye \\ 3 Çiğli Bölge Eğitim Hastanesi, Radyoloji Bölümü, İzmir, Türkiye \\ 4 Sağlık Bilimleri Üniversitesi, İzmir Dr. Behçet Uz Çocuk Hastalıkları ve Cerrahisi Eğitim ve Araştırma Hastanesi, Çocuk Endokrinoloji Kliniği, İzmir, Türkiye
}

Yazıșma Adresi

Correspondence Address

\section{Aynur BEDEL}

Akdeniz Üniversitesi Tıp Fakültesi, Çocuk Endokrinoloji Bilim Dalı,

Antalya, Türkiye

bedelaynur@gmail.com

Geliş tarihi / Received : Aralık 24, 2020 Kabul tarihi / Accepted : Mart 042021

Elektronik yayın tarihi : Ocak 01, 2022

Online published

Bu makalede yapılacak atıf:

Cite this article as:

Bedel A, Tuhan H, İsmailoğlu E,

Özalp Kızılay D, Acar S.

Obez ve Obez Olmayan Polikistik

Over Sendromlu Adolesanların Klinik

ve Laboratuvar Özelliklerinin

Karşıllaştırılması.

Akd Tip D 2022; 8(1):75-81.

Aynur Bedel

ORCID 0000-0001-6074-7606 Hale Tuhan

ORCID 0000-0002-7637-9630

Eren İsmailoğlu

ORCID 0000-0001-9998-6081

Deniz Özalp Kızılay

ORCID 0000-0003-4529-4404

Sezer Acar

ORCID 0000-0002-0768-835X

\section{öz}

Giriş/Amaç:

Bu çalışmanın amacı, obez ve obez olmayan Polikistik Over Sendromu tanılı kız çocuklarındaki klinik ve laboratuvar bulgularının değerlendirilmesidir.

\section{Yöntem:}

Çalışmaya yaşları 13-18 arasında değişen 54 Polikistik Over Sendromu tanılı adolesan olgu dahil edildi. Obez ve obez olmayan Polikistik Over Sendromu tanılı olguların klinik, demografik, laboratuvar ve pelvik ultrasonografi bulguları karşılaştırıldı.

\section{Bulgular:}

Obez ve obez olmayan gruplar karşılaştıııldığında serum; folikül stimule edici hormon (FSH), lüteinleştirici hormon (LH), serbest testosteron, dehidroepiandrosteron sülfat, 17-OH progesteron, androstenedion, açlık kan şekeri, düşük dansiteli lipoprotein düzeyleri ve pelvik ultrasonografi iki grupta benzer bulundu. Obez olgularda, açlık insülin düzeyi, HOMA-IR skoru, trigliserid düzeyi anlamlı olarak daha yüksek iken, yüksek dansiteli lipoprotein ise düşük saptand. Androjen düzeyleri ile bel çevresi, kol çevresi, derialtı yağ kalınlığı, vücut yağ oranı ve over volümleri arasında ilişki saptanmaz iken LH/FSH oranı ile serbest testosteron, 17-OH progesteron ve androstenedion düzeyleri arasında pozitif korelasyon saptandı.

\section{Sonuç:}

Adolesan dönemde Polikistik Over Sendromu tanısı konulduğunda mutlaka metabolik sendrom açısından değerlendirme yapılmalıdır. Metabolik sendrom riski saptanan olgularda bu dönemde dengeli diyet ve düzenli egzersiz alışkanlığı edinmek erişkinlik döneminde eşlik edebilecek komorbid hastalıklar sıklığının azaltılmasında anahtar rol oynamaktadır.

Anahtar Sözcükler: Polikistik over sendromu, Adolesan, Obezite, Hirsutizm

\section{ABSTRACT}

\section{Objective:}

The present study aimed to evaluate the clinical and laboratory findings in obese and non-obese girls diagnosed with Polycystic Ovary Syndrome.

\section{Methods:}

The total sample size was obese and non-obese 54 adolescents diagnosed with Polycystic Ovary 
Bedel A. ve ark.

Syndrome aged between 13-18 years. Demographic, clinic, laboratory, and pelvic ultrasonography findings of both groups were compared.

\section{Results:}

Both obese and non-obese adolescents with PCOS features have shown similarities in the levels of serum Follicle-stimulating hormone (FSH), luteinizing hormone ( $\mathrm{LH})$, free testosterone, dehydroepiandrosterone sulfate, $17-\mathrm{OH}$ progesterone, androstenedione, fasting blood glucose, low-density lipoprotein levels and pelvic ultrasonography. Fasting insulin level, HOMA-IR score, and triglyceride level were significantly higher in obese patients, though high-density lipoprotein was found to be low. There was no correlation between androgen levels and waist circumference, arm circumference, subcutaneous fat thickness, body fat ratio, and ovarian volume. A positive correlation was found between LH / FSH ratio and free testosterone, $17-\mathrm{OH}$ progesterone and androstenedione levels.

\section{Conclusions:}

Adolescents diagnosed with the Polycystic Ovary Syndrome should be evaluated in terms of metabolic syndrome. In cases with metabolic syndrome risk, healthy balanced diet accompanied by regular exercise play an important role in reducing the frequency of comorbid diseases that can occur in adulthood.

Key Words: Polycystic ovary syndrome, Adolescent, Obesity, Hirsutism

\section{GIRIS}

Polikistik over sendromu (PKOS) sıklıkla adolesan dönemde başlayan başlica ovulatuvar disfonksiyon ve hiperandrojenizm ile karakterize heterojen kliniğe sahip bir hastalıktır (1). Buna ek olarak, bu hastalık artmış metabolik sendrom, tip 2 diyabet, kardiyovasküler hastalık ve endometriyal karsinom riski ile ilişkilendirilmektedir (2). Adolesanlarda sıklığ 1 \%6-18 aralığında bildirilmektedir (3). Polikistik over sendromunun etiyolojisi tam olarak aydınlatılamamış olmakla birlikte genetik yatkınlık ve androjen fazlalığı hastalığın patogenezinde önemli rol oynar (1).

Adolesan dönemde erişkin dönemden farklı olarak menarştan iki y1l sonra devam eden adet düzensizliği, klinik ve/veya laboratuvar olarak kanıtlanmış hiperandrojenizm bulguları PKOS tanı kriterleri olarak kullanılırken, polikistik over morfolojisinin pubertal dönemde gözlenen fizyolojik değişikliklerle karışması sebebiyle tanı kriteri olarak kullanılması önerilmemektedir (1).

Polikistik over sendromu tanılı adolesanlarda insülin direnci, hiperinsülinemi, tip 2 diyabet ve obezite birlikteliğinin sık olduğu bilinmektedir. PKOS'lu olgulardaki obezite sıklığ1 $\% 30$ ile \%75 arasında değişen oranlarda bildirilmektedir (4). Obezitenin eşlik ettiği PKOS'lu olgularda metabolik sendrom riskinin 14 kat arttığı gösterilmiştir (5). Obeziteye ek olarak, vücut yağ dağılımı da önem arz etmektedir. Öyle ki, PKOS'lu olgulardaki abdominal yağlanma ile metabolik sendrom gelişimi arasındaki yakın ilişki pek çok çalışmada gösterilmiştir (6). Bu nedenle, PKOS'lu olgularda obezite gelişimi ve özellikle visseral yağlanmanın ortaya çıkması mortalite ve morbiditeyi arttırıcı yönde etki etmektedir.

Polikistik over sendromlu olgularda obeziteden bağımsız olarak artan insülin düzeyi adrenal ve gonadal steroidogenezis ve dolayısıla androjen sekresyonunu (testosteron) arttırır (1). İnsülin mitojenik özellikteki bu etkisini hipotalamo-hipofizer-gonadal aksının çeşitli dokularında bulunan insülin reseptörleri üzerinden gerçekleştirir ve bu yolla steroidogenezisi etkiler. Hiperinsülinizm etkisi ile artan serum androjen düzeyleri cinsiyet hormonu bağlayicı globülin (SHBG) sentezinin azalmasına ve hiperandrojenizm kliniğinin derinleşmesine yol açar. İlginç olarak, karaciğer, iskelet kası ve yağ dokusunda insülin direnci gözlenirken steroid üreten dokular ve hipofiz insülin duyarlılığını korur (insülin sinyal paradoksu) $(1,7)$.

$\mathrm{Bu}$ çalışmanın amacı, PKOS tanılı kız çocuklarının klinik ve laboratuvar bulgularının değerlendirilmesi ve obezitenin PKOS üzerine etkisinin değerlendirmesidir.

\section{GEREÇ, ve YÖNTEM}

Çalışma tek merkezli yapılmış olup yaşları 13-18 arasında olan 54 PKOS tanılı adolesan içermektedir. Çalışmaya dahil edilen tüm hastalar Çiğli Bölge Eğitim Hastanesi Çocuk Endokrinoloji polikliniğinde, Çocuk Endokrinoloji uzmanı tarafından değerlendirildi. Çalışmaya dahil edilme kriterleri; 13-18 yaş arasında olma, ilk adet tarihinden sonra en az iki yıl geçmiş olması ve i) oligo- ve/veya amenore, ii) klinik veya biyokimyasal hiperandrojenizm bulgularının varlığı (1). Pelvik ultrasonografide polikistik over görünümü (over volümünün $>10 \mathrm{ml}$ olması, periferik yerleşimli 2-9 mm çapında 12 den fazla folikül kisti varlığı) destekleyici bulgu olarak kullanılmıştır. Kronik hastalığı olan olgular, herhangi bir ilaç kullanan olgular çalışmadan çıkarıldı. Serum tiroid stimüle edici hormon düzeyi ile tiroid disfonksiyonu, serum bazal 17-OH progesteron düzeyi ile geç başlangıçlı konjenital adrenal hiperplazi, serum prolaktin düzeyleri ile hiperprolaktinemi dışlandı.

Çalışma için Sağlık Bilimleri Üniversitesi İzmir Dr. Behçet Uz Çocuk Hastalıkları ve Cerrahisi Eğitim ve Araştırma Hastanesi Klinik Araştırmalar Etik Kurulu'ndan 25.04.2019 tarihinde 2019/294 protokol numarası ile izin alınmış ve Helsinki kriterlerine uygun olarak yürütülmüştür.

Tüm olguların boy, vücut ağırlığı, bel ve kalça çevresi ölçümleri yapıldı. Vücut ağırlığı giysilerle sabah 12 saatlik açlık sonrası ölçüldü. Boy ölçümleri çıplak ayakla, ayakta dik durumda ve derin inspirasyonda yapıldı. Beden kitle indeksi, vücut ağırlığının boyun metre cinsinden karesine oranları ile elde edildi (ağırlık/boy ${ }^{2}=\mathrm{kg} / \mathrm{m}^{2}$ ). Kan basıncı ölçümleri 10 dakika oturarak dinlendikten sonra uygun manşon ile yapıldı. Olguların vücut yağ analizi "TANITTA MC 780 P" marka BİA kullanılarak sabah 12 saatlik açlık sonrası ölçüldü. Olguların hirsutizm skoru modifiye Ferriman-Gallwey (FG) skorlamas1 yöntemi ile yapıldı. Ferriman-Gallwey puanı $<8$ olanlar normal kabul edildi (8). Ferriman-Gallwey puanı 8-15 arasında olanlar hafif hirsutizm; 16-25 arasinda orta hirsutizm; 25-36 arasında şiddetli hirsutizm olarak değerlendirildi $(8,9)$. 
Obez ve Obez Olmayan Polikistik Over Sendromlu Adolesanların Klinik ve Laboratuvar Özelliklerinin Karşılaştırılması

Hastaların kan örnekleri 12 saatlik açlık sonrası sabah 08:00 ile 09:00 saatleri arasında alındı. Lüteinleştirici hormon, fsh ve 17-OH progesteron foliküler fazda değerlendirildi. Olguların açlık serum glukoz düzeyi hekzokinaz yöntemi ile; alanin amino transferaz (ALT) ve lipitleri [HDL (high density lipoprotein), LDL (Low-density lipoprotein), trigliserid] spektrofotometrik yöntem ile; folikül stimule edici hormon (FSH), lüteinleştirici hormon (LH), total testosteron, dehidroepiandrosteron sülfat (DHEAS), androstenedion, prolaktin, adrenokortikotropik hormon (ACTH), kortizol düzeyleri kemilüminesans immunoassay yöntemi ile; açlık insülin, serbest testosteron, 17-OH progesteron radioimmunoassay yöntemi ile ölçüldü.

'Homeostasis Model 17 Assesment-Insulin Resistance' (HOMA-IR) skoru, açlık insülini $(\mu \mathrm{U} / \mathrm{ml}) \mathrm{x}$ açlık serum glukozu (mg/dl)/405 formülüne göre hesaplandı. HOMA-IR skoru $>3,5$ olanlar insülin direnci olarak kabul edildi (10). Hastaların yapılan pelvik ve üst batın ultrasongrafi bulguları kaydedildi. Over hacminin $10 \mathrm{ml}$ 'nin üzerinde olması veya iki-dokuz mm çaplı, 12 veya daha fazla kistin varlığ durumunda polikistik over morfolojisi olarak değerlendirildi.

\section{Istatistik}

İstatistiksel analiz SPPS 21,0 (SPSS Inc., Chicago, IL, ABD) programı kullanılarak yapıldı. Tüm veriler ortalama \pm standart sapma (SS) veya ortanca (interquartile range (IR)-çeyrekler açıklığı (ÇA)) olarak verildi. Verilen homojen dağılımı Kolmogorov-Smirnov testi kullanılarak değerlendirildi. Homojen dağılım gösteren verilerin karşılaştırılmasında Student $\mathrm{T}$ testi, homojen dağılım göstermeyen verilerin karşılaştırılmasında Mann-Whitney U testi kullanıldı. Grup oranlarının karşılaştırılmasında ki-kare testi uygulandı. Parametrelerin birbiri ile olan ilişkisi, normal dağ 1 lım durumuna göre, Pearson ya da Spearman korelasyon analizi ile gerçekleştirildi. $\mathrm{P}$ değeri $<0,05$ olması istatistiksel olarak anlamlı kabul edildi.

\section{BULGULAR}

Çalışmaya toplam 54 PKOS tanılı adolesan (22 obez, 32 obez olmayan) dahil edildi. Olguların klinik, demografik ve laboratuvar özellikleri Tablo I'de belirtilmiştir.
Tablo I. Hastaların antropometrik, klinik ve laboratuvar özellikleri

\begin{tabular}{|c|c|}
\hline Tanı yaşı & $16,0(15,0-16,7)^{*}$ \\
\hline \begin{tabular}{|l|} 
Menarş yaş1 \\
\end{tabular} & $12,0(11,0-13,0)^{*}$ \\
\hline Ağrllık SDS & $0,91 \pm 1,74^{* *}$ \\
\hline Boy SDS & $0,19 \pm 1,0^{* *}$ \\
\hline VKI SDS & $0,71 \pm 1,57^{* *}$ \\
\hline \begin{tabular}{|l|} 
Obez/Obez olmayan \\
\end{tabular} & $22(\% 40,7) / 32(\% 59,3)$ \\
\hline \begin{tabular}{|l} 
Tansiyon sistolik $(\mathrm{mm} / \mathrm{Hg})$ \\
\end{tabular} & $110(100-111,3)^{*}$ \\
\hline \begin{tabular}{|l} 
Tansiyon diyastolik $(\mathrm{mm} / \mathrm{Hg})$ \\
\end{tabular} & $67,5(60-71,3)^{*}$ \\
\hline FGS & $9(3-12)^{*}$ \\
\hline Hirsutizm (var/yok) & $31(\% 57,4) / 23(\% 42,6)^{*}$ \\
\hline Akne (var/yok) & $13(\% 24,1) / 41(\% 75,9)^{*}$ \\
\hline Akantozis (var/yok) & $8(\% 14,8) / 46(\% 85,2)^{*}$ \\
\hline Stria (var/yok) & $5(\% 9,3) / 49(\% 90,7)^{*}$ \\
\hline VYO (\%) & $28,5 \pm 7,6^{* *}$ \\
\hline VYO (dü̧̧̈ük /normalyükssek) & $2(\% 3,8) / 13(\% 25) / 37(\% 71,2)^{* * *}$ \\
\hline Bel çevresi $(\mathrm{cm})$ & $82,3 \pm 13,1^{*}$ \\
\hline Kol çevresi (cm) & $25,9 \pm 3,3^{*}$ \\
\hline Deri altı yağ kalınliğ $(\mathrm{mm})$ & $25,6 \pm 7,73^{*}$ \\
\hline Açlık kan şekeri (mg/dL) & $87,3 \pm 7,7^{*}$ \\
\hline Insülin $(\mu \mathrm{IU} / \mathrm{mL})$ & $12(9,1-17,9)^{* *}$ \\
\hline HOMA-IR (mmol/L) & $2,75(2,1-3,98)^{* *}$ \\
\hline $\mathbb{R}(\operatorname{var} / \mathrm{yok})(\mathrm{n}=52)$ & $13(\% 25) / 39(\% 75)^{*}$ \\
\hline LH/FSH & $2,25(1,07-2,79)^{*}$ \\
\hline DHEAS (ug/dL) & $364(271-422)^{*}$ \\
\hline Serbest testosteron $(\mathrm{pg} / \mathrm{mL})$ & $2,20(1,70-2,78)^{*}$ \\
\hline Total testosteron $\mathrm{ng} / \mathrm{ml}$ & $0,50(0,40-0,63)^{*}$ \\
\hline 17-hidroksiprogesteron $(\mathrm{pg} / \mathrm{mL})$ & $1,79 \pm 0,64^{* *}$ \\
\hline Androstenedion (ng/mL) & $3,91 \pm 1,65^{* *}$ \\
\hline Toplam over hacmi (ml) & $30,6(12-20,7)^{*}$ \\
\hline
\end{tabular}

*Ortalama \pm standart sapma (SS), ***ortanca (interquartile range (IR)-çeyrekler açıklığ1 (ÇA)) ve n (\%) olarak verilmiştir. VKİ: Vücut kütle indeksi, FGS: Ferriman-Gallwey skoru, VYO: Vücut yağ oranı, FSH: folikül stimule edici hormon, LH: lüteinizan hormone, HOMA-IR: Homeostatic Model Assessment for Insulin Resistance, IR: İnsülin direnci, DHEAS: dehidroepiandrosteron sülfat.

Obez grup ile obez olmayan grup karşılaştırıldığında yaş, boy, menarş yaşı, FGS skoru, hirsutizm, akne varlığ 1 , sistolik ve diyastolik kan basıncı açısından gruplar arasında istatistiksel olarak anlamlı farklılık saptanmazken, obez olgularda vücut kitle indeksi SDS ve vücut yağ oranı anlamlı olarak daha yüksekti $(p<0,001)$ (Tablo II).

Tablo II. Obez ve obez olmayan hasta gruplarının antropometrik ve klinik özellikleri

\begin{tabular}{|l|l|l|l|}
\hline & Obez Olmayan & Obez & $P$ \\
\hline Yaș (yıl) & $15,8 \pm 1,2$ & $15,6 \pm 1,5$ & $0,412^{*}$ \\
\hline Menarș yaşı (yl) & $12,0(11,1-13,0)$ & $12,0(11-13)$ & $0,978^{* *}$ \\
\hline VKI SDS & $-0,1 \pm 1,5$ & $1,9 \pm 0,7$ & $<0,001^{*}$ \\
\hline FGS & $9,5(4-11,8)$ & $9(3-14,2)$ & $0,866^{* *}$ \\
\hline Hirsutizm & $18 / 14$ & $13 / 9$ & $0,836^{* * *}$ \\
\hline Akne (var/yok) & $8 / 24$ & $5 / 17$ & $0,848^{* * *}$ \\
\hline VYO (\%) & $24,9 \pm 7,3$ & $33,4 \pm 4,8$ & $<0,001^{*}$ \\
\hline VYO (d/n/y) & $2 / 13 / 15$ & $0 / 0 / 22$ & $<0,001^{* * *}$ \\
\hline SKB (mmHg) & $110(100-114)$ & $110(110-111)$ & $0,201^{* *}$ \\
\hline DKB (mmHg) & $67,5(60-73,8)$ & $67,5(60-71,2)$ & $1,0^{* *}$ \\
\hline
\end{tabular}


Ortalama \pm standart sapma (SS), ortanca (interquartile range (IR)-çeyrekler açıklığı (ÇA)) ve n (\%) olarak verilmiştir. *Student's t testi, **Mann-Whitney U testi, ${ }^{* * *}$ Chi-Square testi, VKİ: Vücut kütle indeksi, FGS: Ferriman Gallvey skoru, VYO (d/n/y): Vücut yağ oranı (düşük/normal/yüksek), SKB: Sistolik kan basıncı, DKB: Diyastolik kan basıncı

Serum FSH, LH, serbest testosteron, DHEAS, 17-OH progesteron, androstenedion, açlık kan şekeri ve LDL düzeyleri iki grupta benzer bulundu ( $\mathrm{p}>0,05)$ (Tablo III). Gruplar arasında pelvik ultrasonografi bulguları karşılaştırıldığında over boyutları arasında istatistiksel olarak anlamlı fark saptanmadı $(p>0,05)$ (Tablo III). Obez olgularda, açlık insülin düzeyi, HOMA-IR skoru, trigliserid düzeyi anlamlı olarak daha yüksek iken, HDL ise anlamlı olarak daha düşük saptand (sırasiyla; $p=0,019, p=0,014, p=0,006$ ve $p=0,001$ ) (Tablo III).

Tablo III. Obez ve obez olmayan hasta gruplarının laboratuvar özellikleri

\begin{tabular}{|l|l|l|l|}
\hline & Obez Olmayan & Obez & $P$ \\
\hline AKȘ (mg/dl) & $86 \pm 6,7$ & $89,2 \pm 8,7$ & $0,145^{*}$ \\
\hline TG (mg/dl) & $81(59-98)$ & $110(78-140)$ & $0,006^{* *}$ \\
\hline LDL (mg/dl) & $92(70,2-102)$ & $85,5(77,2-100)$ & $0,533^{* *}$ \\
\hline HDL (mg/dl) & $55,7 \pm 12,1$ & $45,0 \pm 7,8$ & $0,001^{*}$ \\
\hline Insülin ( $\mu$ IU/mL) & $11,7(8,6-11,7)$ & $15,2(10,8-26,5)$ & $0,019^{* *}$ \\
\hline HOMA-IR (mmol/L) & $2,3(1,7-3,0)$ & $3,4(2,4-5,7)$ & $0,014^{* *}$ \\
\hline İnsülin direnci (+/-) & $3 / 28$ & $10 / 11$ & $0,002^{* * *}$ \\
\hline FSH (mIU/mL) & $5,5 \pm 1,2$ & $5,3 \pm 1,1$ & $0,679^{*}$ \\
\hline LH (mIU/mL) & $13,9(5,5-19)$ & $12,1(4,8-14,1)$ & $0,149^{* *}$ \\
\hline LH/FSH & $2,3(1,1-3,3)$ & $2,2(1,0-2,6)$ & $0,263^{* *}$ \\
\hline DHEAS (ug/dL) & $353(288-397)$ & $389(249-436)$ & $0,438^{* *}$ \\
\hline Serbest testosteron (pg/mL) & $2,2(1,6-2,57)$ & $2,4(1,8-3,57)$ & $0,200^{* *}$ \\
\hline 17-Hidroksiprogesteron(ng/ml) & $1,7(1,2-2,1)$ & $1,5(1,6-2,1)$ & $0,716^{* *}$ \\
\hline Androstenedion (ng/mL) & $3,7(3,0-4,7)$ & $4,2(2,7-4,7)$ & $0,597^{* *}$ \\
\hline Toplam over hacmi (ml) & $31,8 \pm 8,5$ & $34,5 \pm 11,2$ & $0,164^{*}$ \\
\hline Hepatosteatoz (var/yok) & $1 / 29$ & $4 / 15$ & $0,067^{* * *}$ \\
\hline
\end{tabular}

Ortalama \pm standart sapma (SS), ortanca (interquartile range (IR)-çeyrekler açıklığı (ÇA)) ve n (\%) olarak verilmiştir. *Student's t testi, **Mann-Whitney U testi, ***Chi-Square testi.AKŞ: Açlik kan şekeri, TG: trigliserid, LDL: Düşük yoğunluklu lipoprotein, HDL: Yüksek yoğunluklu lipoprotein, FSH: Folikül stimule edici hormon, LH: Lüteinizan hormone, HOMA-IR: Homeostatic Model Assessment for Insulin Resistance, DHEAS: dehidroepiandrosteron sülfat.

LH/FSH oranı ile serbest testosteron, 17-OH progesteron ve androstenedion düzeyleri arasında pozitif korelasyon

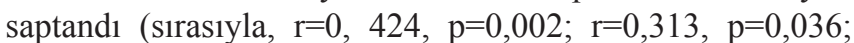
$\mathrm{r}=0,374, \mathrm{p}=0,016$ ). Androjen düzeyleri ile bel çevresi, kol çevresi, derialtı yağ kalınlığı, vücut yağ oranı ve over volümleri arasında ilişki saptanmadı $(\mathrm{p}>0,05)$.

\section{TARTIŞMA}

Prepubertal ve peripubertal obezitenin, PKOS gelişiminde katkıda bulunan faktörler arasındaki önemi gittikçe artmak- tadır. Genetik yatkınlığı olan kişilerde, özellikle beslenme gibi birçok çevresel faktörler PKOS'un klinik ve biyokimyasal fenotipini etkilemektedir $(1,11)$. Polikistik over sendromunun hiperinsülinemi, metabolik disfonksiyon ve hiperandrojenemi gibi özellikleri aşırı yağ dokusunun birikmesi ile ilişkilendirilmektedir. Polikistik over sendromu tanısını alan adolesanların üçte birinin, genel popülasyondaki adolesanların ise \%5'inin metabolik sendrom kriterlerine uyduğu bildirilmiştir (risk faktörleri; obezite, hiperglisemi, dislipidemi ve hipertansiyon) (12-14). Artmış abdominal obezite ve adipoz doku dağılımı vücut kitle indeksinden bağımsız olarak PKOS ile ilişkili metabolik bozuklukları arttırmaktadır (15). Çalışmamızda PKOS tanılı olguların \% 40,7'sinin obez olduğu, \% 71,2'sinin vücut yağ oranının yüksek olduğu görülmüştür. Ezeh ve ark. (16) PKOS tanılı bir grup yetişkin kadın hastayı incelemiş ve artan yağ / kas oranıyla karakterize, olumsuz bir vücut kompozisyonu bulmuşlardır. Gruplar arasında sadece VKİ'yi karşılaştıran çalışmalarda, PKOS tanılı adolesanların, kontrol grubuna kıyasla anlamlı derecede daha yüksek VKİ'ye sahip oldukları bildirilmiştir (17). Buna karşılık Geronikolou ve ark. (18) adolesan PKOS'lu hastalar ve sağlıklı gruplar arasında biyoimpedans yöntemi kullanılarak ölçülen vücut kitle bileşiminde istatistiksel olarak anlamlı bir fark bulunmadığını göstermişlerdir. Çalışmamızda, olguların \%71,2'i yüksek yağ oranı, \%25'i normal yağ oranı ve \%3,8'i ise düşük yağ oranına sahipti.

Polikistik over morfolojisi, artan stroma ve daha küçük periferik kistlere sahip genişlemiş overler olarak tanımlanır. $\mathrm{Bu}$ tanım PKOS için erişkin dönemde tanı kriterlerinden biri olarak kullanılmaktadır (19). Fakat bu kriterin adolesan yaş grubunda kullanılması önerilmemektedir (1). Bunun sebebi, pubertede fizyolojik olarak overlerin polikistik görünüme sahip olabilmesidir. İkinci sınırlayıcı faktör olarak adolesan k1zlarda transabdominal ultrasonografi tercih edilmesi sayılabilir. Transabdominal ultrasonografi tekniğinin güvenirliği kilolu ve obez olgularda sinırlıdır. Polikistik over morfolojisi, adolesan kızlarda tutarsız bir bulgudur ve anovülasyon veya metabolik anormallikler ile ilişkili değildir $(1,20)$. Bu nedenle, adolesan k1zlarda pelvik ultrasonografi yol gösterici değildir. Bizim çalışmamızda da, obez ve obez olmayan gruplar arasında over morfolojisi arasında anlamlı fark saptanmadi.

Polikistik over sendrumunun patofizyolojisinde androjen fazlalığı önemli rol oynamaktadır (1). Adolesanlarda hirsutizm veya akne gibi artmış androjen klinik bulguları PKOS'un değerlendirilmesinde katkı sağlayabilir. $\mathrm{Bu}$ yaş grubunda ciddi akne varlığı özellikle DHEAS düzeyleri ile ve daha az derecede total ve serbest testosteron düzeyleri ile ilişkilendirilmiştir (1,21). Çalışmamızdaki olguların \%24,1'inde akne saptanmış olup \%75,9 olguda akne yakınması yoktu. Hiperandrojenizm klinik semptomlarının güvenilirliğinin düşük olması sebebiyle serum androjen düzeyleri adolesanlarda hiperandrojeneminin en iyi göstergesi kabul edilir. Normal pubertal gelişimde androjen seviyelerinde fizyolojik artış beklense de, biyokimyasal hiperandrojenemi PKOS tanısı koymada önemini korumaya devam etmektedir $(1,22)$. Serum total testosteron (T), SHBG, serbest androjen indeksi (T/SHBGx100), serbest testosteron, androstenedion ve DHEAS biyokimyasal olarak hiperandrojeneminin değer- 
lendirilmesinde kullanılır (23). Çalışmamızda her iki gruptaki olgularda biyokimyasal hiperandrojenemi saptanmış olup obez ve obez olmayan olgular karşılaştırıldığında anlamlı fark saptanmamıştır.

Polikistik over sendromu patogenezinde gonadotropin salgılatıcı hormon (GnRH) salınım sıklığının artması ile LH ve FSH sekresyon sıklığında değişiklikler meydana gelir. Buna bağlı olarak teka hücrelerinde androjen sentezi artar $(1,24,25)$. Polikistik over sendromu patogenezinde bir diğer önemli nokta ise insülin direncidir. İnsülin, PKOS'ta ortaya çıkan hiperandrojeneminin patogenezinde iki farklı rol oynar. Polikistik over sendromunda insülin invitro teka hücrelerinde LH ile sinerjik etki yaparak androjen üretimini uyarır. Aynı zamanda hepatik SHBG sentezinin inhibisyonuna sebep olur (25). Bu etkileri ile plazmada dolaşan serbest testosteron seviyelerinin artmasına neden olur. Polikistik over sendromu tanılı olguların önemli bir kısmında tespit edilen hiperinsülinemi, total testosteron miktarı normal veya hafif yüksekken bile serbest testosteronun yüksek olmasına neden olur (26). Çalışmamızda, bu bulgular ile uyumlu olarak, LH/FSH oranı ile serbest testosteron, 17-hidroksiprogesteron ve androstenedion düzeyleri arasında pozitif korelasyon saptandı. Obez ve obez olmayan olgular karşılaştırıldı̆̆ında ise FGS, hirsutizm varlığ1, LH/FSH oranı, serbest testosteron, DHEAS, 17-OH progesteron düzeyleri ve over boyutları arasında fark yoktu. Klinik hirsutizm açısından değerlendirildiğinde tüm olguların \%57,4'ü klinik hirsutizm tanıs1 alırken \%42,6 olguda klinik hirsutizm tanıs1 yoktu.

Polikistik over sendromu tanısal yaklaşımında LH, LH/FSH oranının kullanımıyla ilgili fikir birliği yoktur. Cho ve ark. (27), kadınlarda LH/FSH oranının doğurganlıkla ilişkisinin PKOS tanılı olan veya olmayan kadınlarda zayıf olduğunu göstermiştir. Escobar Morreale ve ark. (28) ise menstrüel siklustan bağımsız olarak rastgele zamanlarda alınan LH, FSH düzeylerinin PKOS'ta tanısal bir değerinin olmadığını göstermiştir. Bunlara karşılık Barth ve ark. (29) erken foliküler fazda bakılan LH/FSH oranlarının PKOS tanılı kadınlarda anlamlı düzeyde yüksek olduğunu göstermişlerdir ve bunun obez ile obez olmayan olgularda farklı patolojilere bağl1 olabileceğini ileri sürmüşlerdir. Yazarlar, LH/FSH oranındaki yüksekliği obez olmayan olgularda hipofizer LH hipersekresyonuna, obez olgularda ise insülin direncine bağlı geliştiğini savunmuşlardır. Çalışmamızda da her iki grupta foliküler fazda değerlendirilen LH/FSH oraları yüksek olarak tespit edildi ve obez olgularla obez olmayan olgular arasında anlamlı fark saptanmadi.

Obezitenin metabolik disfonksiyon gelişiminde önemi bilinse de PKOS'ta hiperandrojeneminin obeziteden bağımsız olarak metabolik sendrom riskini arttırdığı gösterilmiştir (30,31). Polikistik over sendromunda obezite sıklığ \%40-60 olarak bilinmektedir (12,32). Farklı coğrafyalarda toplumlarda görülen genel obezite prevalansı değişkenlik gösterir. Buna bağlı olarak PKOS olgularında obezite prevalansı ülkelere göre farklılık gösterebilir. Polikistik over sendromu tanılı olgularda obezite sıklıkla bel/kalça oranının $\operatorname{arttı̆̆}_{1}$ santral obezite tipinde olup beraberinde ek riskler getirmektedir. Artmış insülin direncinin PKOS gelişiminde anahtar rol oynaması sebebiyle birinci basamak tedavi yaklaşımında mevcut normal kilonun korunması veya fazla kilolu / obez olgularda kilo kaybı yer almaktadır (12). Yapılan çalışmalarda, tanı anındaki vücut ağırlığında \%10 kaybın düzenli menstrüel döngünün sağlanmasında, fertilitenin artmasında ve dokulardaki insülin duyarlılığının artmasına bağlı olarak metabolik parametrelerde iyileşmede yardımcı olduğu gösterilmiştir $(32,33)$.

Polikistik over sendromu tanılı kadınlarda obezite, hipertansiyon, dislipidemi ve hiperglisemi olarak tanımlanan metabolik sendrom prevalansı yaklaşık üç kat daha yüksektir (34). Adolesanlarda, uzlaşılan metabolik sendrom pediatrik tanı kriterleri yetişkin kriterlerine dayanmaktadır ve yüksek trigliserid konsantrasyonu, yüksek LDL kolesterol konsantrasyonu, açlık kan şekerinin $\geq 110 \mathrm{mg} / \mathrm{dL}$ olması, artmış bel çevresi ve hipertansiyonu içermektedir (33). Bizim çalışmamızda açlık insülin düzeyi, HOMA-IR skoru, dislipidemi (trigliserid yüksekliği, HDL kolesterol düşüklüğü) obez grubunda anlamlı olarak daha yüksek saptandı. Roe ve ark. (17) PKOS tanılı adolesan olgularda önemli ölçüde artmış metabolik sendrom riski geliştiğini ve beraberinde genç erişkinlik döneminde asemptomatik koroner ve aortik ateroskleroz gibi kardiyovasküler hastalıkların sıklığını arttırdığını göstermiştir.

\section{SONUÇ}

Polikistik over sendromu hayatın erken dönemlerinde başlayan ve erişkinlik döneminde devam eden karmaşık bir kadın endokrinopatisidir. Adolesan dönemde PKOS tanısı alan hastaların metabolik sendrom açısından değerlendirilmesi gereklidir. Çocukluk çağı obezitesinin gün geçtikçe artıyor olması, PKOS semptomlarını şiddetlendirebilir. Adolesan dönemde dengeli diyet ve düzenli egzersiz alışkanlı̆ğ edinmek erişkinlik döneminde eşlik edebilecek komorbid hastalıklar sıklığının azaltılmasında anahtar rol oynamaktadir.

Etik Komite Onayı: Çalışma için Sağlık Bilimleri Üniversitesi İzmir Dr. Behçet Uz Çocuk Hastalıkları ve Cerrahisi Eğitim ve Araştırma Hastanesi Klinik Araştırmalar Etik Kurulu'ndan 25.04.2019 tarihinde 2019/294 protokol numarası ile izin alınmıştır.

Hasta Onamı: Çalışma retrospektif olarak yürütülmüş olup hastalardan yazılı bilgilendirilmiş onam alınmamıştır.

Yazar Katkıları : Fikir - H.T., S.A.; Tasarım - A.B., D.Ö.K.; Denetleme - H.T., D.Ö.K.; Kaynaklar-A.B., E.İ., S.A., H.T.; Malzemeler - A.B., E.İ., H.T.; Veri Toplanması ve/veya İşlemesi - E.İ., A.B.; Analiz ve/veya Yorum - H.T., A.B., D.Ö.K., E.İ.; Literatür Taraması - A.B., E.İ., S.A., H.T.; Yazıyı Yazan - A.B., H.T.; Eleştirel İnceleme - E.İ, D.Ö.K., S.A.

Çıkar çatışması: Yazarların beyan edecek çıkar çatışması yoktur.

Finansal Destek: Yazarlar bu çalışma için finansal destek almadıklarını beyan etmişlerdir. 
Bedel A. ve ark.

\section{KAYNAKLAR}

1. Ibáñez L, Oberfield S.E, Witchel S, Auchus R.J, Chang R.J, Codner E, Dabadghao P, Darendeliler F, Elbarbary N.S, Gambineri A, Garcia Rudaz C, Hoeger K.M, López-Bermejo A, Ong K, Peña A.S, Reinehr T, Santoro N, Tena-Sempere M, Tao R, Yildiz B.O, Alkhayyat H, Deeb A, Joel D, Horikawa R, de Zegher F, Lee P.A. An International Consortium Update: Pathophysiology, Diagnosis, and Treatment of Polycystic Ovarian Syndrome in Adolescence. Horm Res Pediatr 2017; 88:371-395.

2. Azziz R, Woods KS, Reyna R, Key TJ, Knochenhauer ES, Yildiz BO. The prevalence and features of the polycystic ovary syndrome in an unselected population. $\mathrm{J}$ Clin Endocrinol Metab 2004; 89:2745-2749.

3. Christensen SB, Black MH, Smith N, Martinez MM, Jacobsen SJ, Porter AH, Koebnick C. Prevalence of polycystic ovary syndrome in adolescents. Fertil Steril 2013; 100(2):470-477.

4. Ehrmann DA. Polycystic ovary syndrome. N Engl J Med 2005; 352:1223-1236.

5. Ehrmann DA, Liljenquist DR, Kasza K, Azziz R, Legro RS, Ghazzi MN. Prevalence and predictors of the metabolic syndrome in women with polycystic ovary syndrome. J Clin Endocrinol Metab 2006; 91:48-53.

6. Moghetti P, Tosi F, Bonin C, Di Sarra D, Fiers T, Kaufman JM, Giagulli VA, Signori C, Zambotti F, Dall'Alda M, Spiazzi G, Zanolin ME, Bonora E. Divergences in insulin resistance between the different phenotypes of the polycystic ovary syndrome. J Clin Endocrinol Metab 2013; 98:628-637.

7. Wu S, Divall S, Wondisford F, Wolfe A. Reproductive tissues maintain insulin sensitivity in diet-induced obesity. Diabetes 2011; 61:114-123.

8. Rosenfield RL. Clinical practice. Hirsutism. N Eng J Med 2005; 353:2578-2588.

9. Martin K, Chang J, Ehrmann DA, Ibanez L, Lobo RA, Rosenfield RL, Shapiro J, Montori VM, Swigloet BA. Evaluation and treatment of hirsutism in premenopausal women: An endocrine society clinical practice guideline. J Clin Endocrinol Metab 2008; 93:1105-1120.

10. Keskin M, Kurtoglu S, Kendirci M, Atabek ME, Yazici C. Homeostasis Model Assessment Is More Reliable Than the Fasting Glucose/Insulin Ratio and Quantitative Insulin Sensitivity Check Index for Assessing Insulin Resistance Among Obese Children and Adolescents. Pediatrics 2005; 115:e500-e503.
11. Littlejohn EE, Weiss RE, Deplewski D, Edidin DV, Rosenfield R. Intractable early childhood obesity as the initial sign of insulin resistant hyperinsulinism and precursor of polycystic ovary syndrome. J Pediatr Endocrinol Metab 2007; 20:41-51.

12. Vatopouloua A, Tziomalos K. Management of obesity in adolescents with polycystic ovary syndrome. Expert Opin Pharmacother 2020; 21(2):207-211.

13. Coviello AD, Legro RS, Dunaif A. Adolescent girls with polycystic ovary syndrome have an increased risk of the metabolic syndrome associated with increasing androgen levels independent of obesity and insulin resistance. J Clin Endocrinol Metab 2006; 91:492-497.

14. Alemzadeh R, Kichler J, Calhoun M. Spectrum of metabolic dysfunction in relationship with hyperandrogenemia in obese adolescent girls with polycystic ovary syndrome. Eur J Endocrinol 2010; 162:1093-1099.

15. Goss AM, Chandler Laney PC, Ovalle F, Lee Goree L, Azziz R, Desmond RA, G. Bates GW, Goweret BA. Effects of a eucaloric reduced-carbohydrate diet on body composition and fat distribution in women with PCOS. Metabolism 2014; 63:1257-1264.

16. Ezeh U, Pall M, Mathur R, Azziz R. Association of fat to lean mass ratio with metabolic dysfunction in women with polycystic ovary syndrome. Hum Reprod 2014; 29:1508-1517. https://doi.org/10.1093/humrep/deu096

17. Roe AH, Prochaska E, Smith M, Sammel M, Dokras A. Using the androgen excess-PCOS society criteria to diagnose polycystic ovary syndrome and the risk of metabolic syndrome in adolescents. J Pediatr 2013; 162:937-941.

18. Geronikolou SA, Bacopoulou F, Cokkinos D. Bioimpedance measurements in adolescents with polycystic ovary syndrome: a pilot study. Adv Exp Med Biol 2017; 987:291-299.

19. The Rotterdam ESHRE/ASRM-Sponsored PCOS Consensus Workshop Group. Revised 2003 consensus on diagnostic criteria and long term health risks related to polycyctic ovary syndrome. Fertil Steril 2004; 81:19-25.

20. Codner E, Villarroel C, Eyzaguirre FC, Lopez P, Merino PM, Perez-Bravo F, German Iniguez G, Cassorla F. Polycystic ovarian morphology in postmenarchal adolescents. Fertil Steril 2011; 95:702-706.

21. Lucky AW, Biro FM, Simbartl LA, Morrison JA, Sorg NW. Predictors of severity of acne vulgaris in young adolescent girls: results of a five-year longitudinal study. J Pediatr 1997; 130:30-39. 
22. Chang WY, Knochenhauer ES, Bartolucci AA, Azziz R. Phenotypic spectrum of polycystic ovary syndrome: clinical and biochemical characterization of the three major clinical subgroups. Fertil Steril 2005; $83: 1717-1723$.

23. The Rotterdam ESHRE/ASRM-Sponsored PCOS Consensus Workshop Group. Revised 2003 consensus on diagnostic criteria and long-term health risks related to polycystic ovary syndrome (PCOS). Hum Reprod 2004; 19:41-47.

24. Caldwell ASL, Edwards MC, Desai R, Jimeneza M, Gilchristb RB, Handelsmana DJ, Walterset KA. Neuroendocrine androgen action is a key extraovarian mediator in the development of polycystic ovary syndrome. Proc Natl Acad Sci USA. 2017; 114:3334-3343.

25. Dabadghao P. Polycystic ovary syndrome in adolescents. Best Pract Res Clin Endocrinol Metab 2019; 33(3): 101272 .

26. Nestler JE, Jakubowicz DJ, De Vargas AF, Brik C, Quintero N, Medina F. Insulin stimulates testosterone biosynthesis by human thecal cells from women with polycystic ovary syndrome by activating its own receptor and using inositolglycan mediators as the signal transduction system. J Clin Endocrinol Metab 1998; 83:2001-2005.

27. Cho LW, Jayagopal V, Kilpatrick ES, Holding S, Atkin $\mathrm{SL}$. The $\mathrm{LH} / \mathrm{FSH}$ ratio has little use in diagnosing polycystic ovarian syndrome. Ann Clin Biochem 2006; 43:217-219.
28. Escobar Morreale HF, Asuncio'n M, Calvo RM, Sancho J, San Milla'n JL. Receiver operating characteristic analysis of the performance of basal serum hormone profiles for the diagnosis of polycystic ovary syndrome in epidemiological studies. Eur J Endocrinol 2001; 145:619-624.

29. Barth JH, Field HP, Yasmin E, Balen AH. Defining hyperandrogenism in polycystic ovary syndrome: measurement of testosterone and androstenedione by liquid chromatography-tandem mass spectrometry and analysis by receiver operator characteristic plots. Eur J Endocrinol 2010; 162:611-615.

30. Fruzzetti F, Perini D, Lazzarini V, Parrini D, Genazzani AR. Adolescent girls with polycystic ovary syndrome showing different phenotypes have a different metabolic profile associated with increasing androgen levels. Fertil Steril 2009; 92:626-634.

31. Rossi B, Sukalich S, Droz J, Griffin A, Cook S, Blumkin A, Guzick DS, Hoegeret KM. Prevalence of metabolic syndrome and related characteristics in obese adolescents with and without polycystic ovary syndrome. J Clin Endocrinol Metab 2008; 93:4780-4786.

32. Diamanti Kandarakis E. PCOS in adolescents. Best Pract Res Clin Obstet Gynaecol 2010; 24:173-183.

33. Zimmet P, Alberti G, Kaufman F, Tajima N, Silink M, Arslanian S, Wong G, Bennett P, Shaw J, Caprio S. The metabolic syndrome in children and adolescents. Lancet 2007; 369(9579):2059.

34. Moran LJ, Misso ML, Wild RA, Norman RJ. Impaired glucose tolerance, type 2 diabetes and metabolic syndrome in polycystic ovary syndrome: a systematic review and meta-analysis. Hum Reprod Update 2010; 16:347-363. 